\title{
EDITORS' NOTE, APRIL 2018
}

In many ways Robert H. Wiebe's monumental book The Search for Order, 1877-1920, anticipated much of the agenda for our current issue. In our Classic Books department, The Search for Order receives here a fiftieth-anniversary reflection and appreciation from Ian Tyrrell. Wiebe, alas, rarely seems to appear much these days on graduate reading lists - even as his primary competitor, Richard Hofstadter's The Age of Reform (1955), still continues to actively shape historiographical debate. Yet although Tyrrell explores some of the important limitations in Wiebe's 1967 master work, he offers, even more, a lively appreciation of the prescience of Wiebe's themes, concerns, and interpretations.

The Search for Order is best known for Wiebe's emphasis on the rise of a "new middle class." Suffusing the book, however, is a thesis of modernization that focuses on the rise of large institutions supplanting local "island communities" in economy, governance, and civic life. Although no economic determinist, Wiebe understood that the creation of a corporate economy led to dramatic changes in the political economy, the relationship between labor and capital, the legal culture, and the shape of reform efforts throughout the Gilded Age and Progressive Era. About all this, Wiebe told a rather detached if not outright amoral tale: any supposed progress from progressivism was often constrained, if not destroyed, by various tendencies toward exclusion and inequalityand, in any case, the nearly inevitable organizational revolution swept all before it. ${ }^{1}$

Christoph Nitschke opens the current issue by following through on Wiebe's emphasis on the importance of economic institutions. Wiebe had an admirably interdisciplinary sense of social theory, and Nitschke uses concepts from economics to help examine and explain the importance of the nascent culture of financial capitalism through the prism of the first great post-Civil War financial panic in 1873. In turn, Mary Furnerherself a doctoral advisee of Robert Wiebe-reiterates the critical importance of elite institutions to the development of American political economy. Her revisionist account of how Supreme Court decisions involving state-level extensions of the "police powers" to employment law provoked a new chapter in the "tortured" history of labor standards regulation speaks to both the first Gilded Age as well as our own second, Janus-oriented, gilded moment. In the final essay in this issue's trilogy relating to political economy and the state, Drew VandeCreek-in part relying on Furner's own pioneering work in this area-examines the ways that the vaunted cosmopolitan "experts" who many scholars (especially Wiebe) believe came to reign in the early twentieth century actually had significant local roots, as well as more complex roles in the formation of the modern American state than previously understood.

The second half of The Search for Order placed progressive reform and reformers at the center of the newness and modernism ushered into American life at the turn of the twentieth century - while firmly demonstrating the reformers' connections to a very concrete past still vividly experienced through the legacy of the Civil War and Reconstruction. In the current issue's next trio of essays, Robert Bland, Shana Bernstein, and Jeffrey Brown reveal the continued value of exploring the complexities of the many different 
kinds of activists who energized the early 1900s. Bland introduces a topic quite novel among historians in 1967-a natural disaster-as the context for bitter political and ideological struggles among black and white reformers as they defended middle-class values against aggressive white supremacists. Bernstein also turns to environmental history to explore the class underpinnings of early twentieth-century reform. Once more crediting the strong middle-class foundation of progressivism, Bernstein emphasizes in her study of Chicago health reform the often (but not always) democratic alliances that such classic reformers made with working-class and poor immigrants, who also cared deeply about forging what we today would call a movement for environmental justice. And Brown further complicates the varieties of class ideologies in the swirl of the early 1900s, where elite intellectuals and salt-of-the-earth workers wrestled with the high European philosophy of vitalism as they grappled with how both to empower workers and embrace a more "real" life.

Although, like Nitschke's initial article, formally outside Wiebe's chronology, Thomas Pegram's exploration of the 1920s Ku Klux Klan and the working class is also very much in the spirit of The Search for Order. Determinedly an anti-romantic labor history, Pegram's essay reveals that white workers, including avowed unionists, were often attracted to the second coming of the KKK. Those wearing white hoods were more than happy to reciprocate this interest, arguing that racism and nativism were white workers' best friends.

The more things change ...

Ultimately, the congruence between Wiebe's classic book of a half century ago and the articles in the current issue perhaps should give us pause in case we are tempted to articulate our own vision of progressivism - in this case, historiographical progressivism. Yes, we advance knowledge when we do our research and writing, and the new themes and issues that are now on our agenda-but were often invisible in 1967-represent genuine progress. Yet, perhaps: speaking somewhat amorally, in the Wiebeesque vein, we might see that amid momentous intellectual changes, the past continues to forcefully constrain us even as we believe ourselves too enlightened to be subject to its genuine power. Indeed, scholars may well be talking about many of these same issues fifty years hence. In ways these discussions will surely be interesting and innovative, but nevertheless perhaps eerily similar.

Robert D. Johnston, C. Joseph Genetin-Pilawa, Benjamin H. Johnson and Boyd Cothran

\section{NOTE}

${ }^{1}$ Compare Wiebe's clinical language in The Search for Order with his considerably more moralistic later books, especially Self-Rule: A Cultural History of American Democracy (Chicago: University of Chicago Press, 1995). 